\title{
Vitamin D and Breast Cancer: Insights in Possible Treatment Options of Breast Cancer
}

\author{
M Friedrich $^{1 *}$, L Kolnsberg ${ }^{1}$ and M Thill ${ }^{2}$ \\ ${ }^{1}$ Department of Obstetrics and Gynecology, Germany \\ ${ }^{2}$ Department of Gynecology and Obstetrics, Agaplesion Markus Hospital, Germany
}

Received: 阱 August 20, 2018; Published: 海 August 27, 2018

*Corresponding author: Michael Friedrich, Director of the Department of Obstetrics and Gynecology, Helios Hospital, Luther Square 40, D-47805 Krefeld, Germany

\section{Mini Review}

Epidemiologic studies have indicated that vitamin D might play a protective role against breast cancer. Incidence of breast cancer and mortality rate considerably vary worldwide and reveal a geographic pattern. The lowest rates of breast cancer generally occur in countries close the equator. With increasing latitude reported breast cancer incidence and mortality rates also increase. A negative correlation between available sunlight and breast cancer death rates has been shown. Because sunlight exposure is a measure of vitamin D produced in the skin, it has been hypothesized that vitamin $\mathrm{D}$ formed in the skin may reduce the risk of breast cancer [1-3]. Breast cancer is the most frequent cause of cancer death in women in the western world. Many studies have tried to identify the casual factors responsible for the uncontrolled growth of the tumor cells. A variety of biochemical and genetic changes have been identified in breast carcinomas and have been found to be related to breast cancer growth.

However, especially because of the heterogeneity of the disease on the clinical, biologic and genetic levels, the exact mechanism of breast cancer development and progression is still unclear. During the last 15 years, it has become evident that 1,25-dihydroxyvitamin $\mathrm{D}_{3}\left(1,25(\mathrm{OH})_{2} \mathrm{D}_{3}\right)$, the biologically most active form of vitamin $\mathrm{D}_{3}$, exerts effects on a variety of tissues which are apparently unrelated to calcium homeostasis. $1,25(\mathrm{OH})_{2} \mathrm{D}_{3}$ has been shown to induce cellular differentiation and inhibit proliferation of hematopoietic cells and cancer cells. In addition, studies with animal cancer models have shown that $1,25(\mathrm{OH})_{2} \mathrm{D}_{3}$ application can prolong the survival of leukemic mice and suppress the growth of tumors of different origins including breast [4,5]. These newly discovered properties suggest a possible role of the hormone in the treatment of cancer. However, a major drawback for a clinical application is that high doses are needed.

These doses produce serum levels of $1,25(\mathrm{OH})_{2} \mathrm{D}_{3}$ far above the physiologic level, which may lead to hypercalcemia. Many investigators have tried to change the $1,25(\mathrm{OH})_{2} \mathrm{D}_{3}$ molecule in order to retain its ant proliferative and differentiation-inducing activity combined with a reduced effect on calcium and bone metabolism. This strategy has resulted in new synthetic vitamin D3 analogs with clinical potential [6-8]. The expression of the vitamin D receptor (VDR) in breast cancer was first demonstrated in the human breast cancer cell line MCF-7 [9]. Further studies have extended this finding even to surgically obtained normal breast and breast tumor tissue [10]. The VDR is expressed in about $80 \%$ of human breast tumor specimens. The VDR status is not correlated to the expression of other steroid hormone receptors (estrogen receptor, progesterone receptor) [11-30] or to the clinical indices (age, menopausal status, T-stage, histology, lymph node involvement) including overall survival [12-31].

Nevertheless, two studies reported that the VDR status correlated positively with the disease-free interval [14-31]. The steroid hormone responsiveness is directly proportional to the number of corresponding receptors. Regulation of the number of VDR may affect the cellular responsiveness to $1,25(\mathrm{OH})_{2} \mathrm{D}_{3}$. In several different systems including MCF-7 and T47-D breast cancer cells, upregulation of the VDR by $1,25(\mathrm{OH})_{2} \mathrm{D}_{3}$ itself (homologous upregulation) and by hormones (estradiol) and growth factors (epidermal growth factor (EGF), insulin, insulin-like growth factor-1 (IGF-1)) has been demonstrated (heterologous upregulation) [2,32-37]. Because VDR mediates the biological effects of calcitriol and analogs on differentiation and proliferation in target cells, VDR upregulation may indicate an increased sensitivity of breast cancer to endogenously or therapeutically applied calcitriol. Thus, a relationship between VDR level and growth inhibition has been suggested for breast cancer cells [38,39].

Nevertheless, the presence of a functional VDR is not always combined with a growth-inhibitory response of $1,25(\mathrm{OH})_{2} \mathrm{D}_{3}$. A lack of growth inhibition by $1,25(\mathrm{OH})_{2} \mathrm{D}_{3}$ independent of the 
status of functional VDR has been demonstrated in breast cancer cells $[40,41]$. The underlying mechanism of this VDR-independent resistance to growth inhibition is unknown. The first studies on the effect of $1,25(\mathrm{OH})_{2} \mathrm{D}_{3}$ on breast cancer cells showed a biphasic growth response of the estrogen receptor-positive T47-D human breast tumor cell line. At low concentrations (10-11 M), a stimulation of cell growth was observed [10, 42, 43]. This growthinhibitory effect of $1,25(\mathrm{OH})_{2} \mathrm{D}_{3}$ was confirmed in other breast tumor cell lines and shown to be independent of the estrogen receptor status $[44,45]$. In the growth inhibited breast cancer cells $1,25(\mathrm{OH})_{2} \mathrm{D}_{3}$ and $1,25(\mathrm{OH})_{2} \mathrm{D}_{3}$ analogs caused an increase of the number of cells in the GO/GI and occasionally in the G2 phase together with a decrease of the number of cells in the $\mathrm{S}$ phase $[40,44,46-49]$ indicating a cell cycle block in the GO/GI phase.

Apoptosis (programmed cell death), is an asynchronous cellular process with cytoplasmic and nuclear condensation, disruption of the cytoskeleton and condensation of intermediate filaments around the nucleus and is related to the cell cycle [50]. Induction of apoptosis can be a possible way in which $1,25(\mathrm{OH})_{2} \mathrm{D}_{3}$ inhibits tumor cell growth. Recently it has been shown that $1,25(\mathrm{OH})_{2} \mathrm{D}_{3}$ induces apoptosis in various tumor cells [40,49,51,52]. A central role for apoptosis in the action of $1,25(\mathrm{OH})_{2} \mathrm{D}_{3}$ is uncertain because growth inhibition of several breast cancer cells appeared to be independent of apoptosis [40]. Thus, the growth stimulation of MCF7 cells, that were growth inhibited by $1,25(\mathrm{OH})_{2} \mathrm{D}_{3}$, after removal of $1,25(\mathrm{OH})_{2} \mathrm{D}_{3}$ indicates independence of growth inhibition from apoptosis [53]. Possibly in these latter cases induction of differentiation is more prominent. Treatment of breast cancer cells with $1,25(\mathrm{OH})_{2} \mathrm{D}_{3}$ resulted in morphologic changes, which may resemble a more differentiated status of the cells $[43,54,55]$.

Induction of differentiation was recently shown in several breast cancer cells [40]. The results of these studies suggest that induction of differentiation and growth inhibition are two independent processes. The various synthetic vitamin $\mathrm{D}_{3}$ analogs have been shown to be more potent than $1,25(\mathrm{OH})_{2} \mathrm{D}_{3}$ in the growth inhibition of several cancer cell types, whereas there in vivo calcemic activity was similar or even reduced compared with $1,25(\mathrm{OH})_{2} \mathrm{D}_{3}$. Mammary tumors can be induced in rats by oral administration of the carcinogens N-nitroso-N-methylurea (NMU) or 7,12-dimethylben(a)anthracene (DMBA). Application of $1,25(\mathrm{OH})_{2} \mathrm{D}_{3}$ resulted in an inhibition of the growth of NMU- $[31,56]$ and DMBA-induced rat mammary tumors $[57,58]$, whereas Noguchi et al. [59] did not find an effect of $1,25(\mathrm{OH})_{2} \mathrm{D}_{3}$ on the incidence and growth of DMBA- induced rat mammary tumors. To achieve tumor suppression, high doses of $1,25(\mathrm{OH})_{2} \mathrm{D}_{3}$ about $0,5 \mathrm{ug} / \mathrm{kg} \mathrm{BW}$ ) were needed with the subsequent development of hypercalcemia and weight loss. Thus, synthetic vitamin $\mathrm{D}_{3}$ analogs with low in vivo calcemic activity have been developed.

Only a few analogs have been evaluated in vivo for their potential use in the treatment of breast cancer. To date, two clinical studies on the effect of vitamin $\mathrm{D}_{3}$ analogs on cancer growth in humans have been reported. Topical application of calcipotriol (MC903) in a small group of patients with locally advanced or cutaneous metastatic breast cancer showed a reduction in the size of treated lesions in 4 of 14 patients [60], whereas another study could not confirm this observation [61]. In a phase I trial the analog EB1089 is being examined in advanced breast cancer, but no detailed analyses have been published. The antiestrogen tamoxifen is the most widely used endocrine agent in the treatment of breast cancer [62]. A major problem of tamoxifen therapy is that in case of response, the tumor almost inevitably progresses to a tamoxifen-resistant state during prolonged therapy. Furthermore, long-term tamoxifen therapy has been linked to an increased risk of endometrial cancer. Therefore, despite the efficacy of tamoxifen for breast cancer, alternative additional endocrine therapies are needed.

Thus, several studies have focused on possible future combination treatment with $1,25(\mathrm{OH})_{2} \mathrm{D}_{3}$ and $1,25(\mathrm{OH})_{2} \mathrm{D}_{3}$ analogs in estrogen receptor-positive and -negative breast cancer. A synergistic antiproliferative effect of submaximum dosages of the vitamin D analog, 22-oxacalcitriol, and tamoxifen in breast cancer cells has been described in vitro and in vivo [63]. Thus, the combined treatment with $1,25(\mathrm{OH})_{2} \mathrm{D}_{3}$ and tamoxifen resulted in stronger growth inhibition of MCF-7 cells than treatment with either compound alone [53]. With a number of vitamins D3 analogs a similar effect was observed [37]. In combination with tamoxifen the cells were more sensitive to the antiproliferative action of $1,25(\mathrm{OH})_{2} \mathrm{D}_{3}$ and the analogs [37]. The ability of tamoxifen to reduce the total tumor burden of rats treated with the carcinogen NMU is significantly enhanced by a combination of the vitamin $\mathrm{D}_{3}$ analog, Ro24-5531, with low doses of tamoxifen [64]. Thus, implications for the use of vitamin $D$ analogs not only in treatment but also in the prevention of breast cancer have been indicated.

Vitamin A-derivatives like fenretinide are currently being tested in clinical trials as preventive agents against recurrence of breast cancer, and animal studies point to a potential use of these compounds as therapeutic agents for breast cancer [65]. A combination therapy of retinoic acid and $1,25(\mathrm{OH})_{2} \mathrm{D}_{3}$ showed a synergisticgrowthinhibition of breastcancercells [66].Furthermore, combinations with vitamin $\mathrm{D}_{3}$ compounds and cytotoxic drugs (TNF, GMCSF, Adriamycin, 5-FU, Carboplatin, Cisplatin) have been studied [45,57,67-69]. The data on combinations of $1,25(\mathrm{OH})_{2} \mathrm{D}_{3}$ and $1,25(\mathrm{OH})_{2} \mathrm{D}_{3}$ analogs with various other anticancer compounds are promising and justifies further analyses. For example, the development of effective combination therapies may result in better response rates and lower dosages combined with a reduced risk of negative side-effects. Invasion and metastasis of tumor cells are the primary causes for the fatal outcome of cancer diseases. A recent report by Mork Hansen et al. [70] indicated that $1,25(\mathrm{OH})_{2} \mathrm{D}_{3}$ may be effective in reducing the invasiveness of breast cancer cells.

They have shown $1,25(\mathrm{OH})_{2} \mathrm{D}_{3}$ inhibited the invasion and migration of a metastatic human breast cancer cell line (MDAMB-231). A fact to be considered in relation to metastasis is that bone is the most frequent site of metastasis of advanced breast cancer [71]. There are some indications from clinical studies that bone metastases develop preferentially in areas with high bone 
turnover $[72,73]$. By contrast, agents that inhibit bone resorption have been reported to reduce the incidence of skeletal metastasis [74]. As $1,25(\mathrm{OH})_{2} \mathrm{D}_{3}$ is an important stimulator of bone resorption and consequently of bone tumover, treatment with $1,25(\mathrm{OH})_{2} \mathrm{D}_{3}$ or vitamin D3 analogs for breast cancer might increase the risk of skeletal metastases. However, Krempien [75] reported that following intraarterial injection with Walker 256 tumor cells, rats treated with $1,25(\mathrm{OH})_{2} \mathrm{D}_{3}$ developed significantly more bone metastases than untreated controls. In relation to this aspect, it was shown that tamoxifen, which exerts positive estrogenic effects on bone [76], considerably suppressed the bone resorption induced by $1,25(\mathrm{OH})_{2} \mathrm{D}_{3}$ ED1089, and KH1060 [77]. These data suggest that in vitamin D-tamoxifen combination therapy for breast cancer tamoxifen may offer protection against the bone resorption induced by vitamin $D_{3}$ compounds and thereby decreases the risk of bone metastases.

Vitamin $\mathrm{D}_{3}$ analogs have potent antiproliferative effects on breast cancer cells in vitro and suppress breast cancer growth in vivo without marked calcemic effects. However, apart from the strong calcemic activity of $1,25(\mathrm{OH})_{2} \mathrm{D}_{3}$ other negative sideeffects may arise, in particular immunosuppressive effects and an increased risk of bone metastases. The development of new vitamin D3 analogs continues. In the future vitamin $\mathrm{D}_{3}$ analogs with even stronger antiproliferative effects and better selectivity may become available. Vitamin D treatment theoretically could be beneficial for a large group of patients, since the VDR is expressed in about $80 \%$ of human breast cancers. Another promising aspect of vitamin D treatment might be its combination with other established endocrine (tamoxifen) or cytotoxic agents. Finally, epidemiologic studies and in-vitro results have suggested a role for vitamin $\mathrm{D}$ in the prevention of breast cancer. In the next few years, clinical studies are needed to confirm that vitamin D3 analogs, either alone or in combination with other antitumor agents, can provide an effective treatment for breast cancer.

\section{References}

1. Garland FC, Garland CF, Gorham ED, Young JF (1990) Geographic variation in breast cancer mortality in the United States: A hypothesis involving exposure to solar radiation. Prev Med 19(6): 614-622.

2. Gorham ED, Garland FC, Garland CF (1990) Sunlight and breast cancer incidence in the USSR. Int J Epidemiol 19(4): 820-824.

3. Ainsleigh HG (1993) Beneficial effects of sun exposure on cancer mortality. Prev Med 22(1): 132-140.

4. Reichel H, Koeffler HP, Norman AW (1989) The role of the vitamin D endocrine system in health and disease. N Engl J Med 320(15): 980-991.

5. Walters MR (1992) Newly identified actions of the vitamin D endocrine system. Endocr Rev 13(4): 719-764.

6. Bikle DD (1992) Clinical counterpoint: Vitamin D new actions, new analogs, new therapeutic potential. Endocr. Rev 13(4): 765-784.

7. Pols HAP, Birkenhäger JC, van Leeuwen JPTM (1994) Vitamin D analogues: from molecule to clinical application. Clin Endocrinol 40(3): 285-292.

8. Bouillon R, Okamura WH, Norman AW (1995) Structure-function relationships in the vitamin D endocrine system. Endocr Rev 16(2): 200-257.
9. Eisman JA, Martin TJ, MacIntyre I, Moseley JM (1976) 1,25 -Dihydroxyvitamin D receptor in breast cancer cells. Lancet 2 (81568157): 1335-1336.

10. Eisman JA (1984) 1,25-Dihydroxyvitamin $\mathrm{D}_{3}$ receptor and role of 1,25 $(\mathrm{OH})_{2} \mathrm{D}_{3}$ in human cancer cells. In: Vitamin D Metabolism: Basic and Clinical Aspects. Kumar R, (eds). The Hague, Martinus Nijhoff pp. 365.

11. Eisman JA, Suva LJ, Sher E, Pearce PJ, Funder JW, et al. (1981) Frequency of 1,25-dihydroxivitamin $\mathrm{D}_{3}$ receptor in human breast cancer. Cancer Res 41: 5121-5124.

12. Freake HC, Abeyasekera G, Iwasaki J, Marcocci C, MacIntyre I, et al. (1984) Measurement of 1,25-dihydroxyvitamin D3 receptors in breast cancer their relationship to biochemical and clinical indices. Cancer Res 44(4): 1677-1681.

13. Berger U, Wilson P, McClelland RA, Colston K, Haussler MR, et al. (1987) Immunocytochemical detection of 1,25-dihydroxyvitamin $\mathrm{D}_{3}$-receptor in breast cancer. Cancer Res 47: 6793-6799.

14. Berger U, McClelland RA, Wilson P, Greene GL, Haussler MR, et al. (1991) Immunocytochemical determination of estrogen receptor, progesterone receptor, and 1,25-dihydroxyvitamin $\mathrm{D}_{3}$ receptor in breast cancer and relationship to prognosis. Cancer Res 51(1): 239-244.

15. Reichrath J, Rafi L, Müller SM, Mink D, Reitnauer K, et al. (1998) Immunohistochemical analysis of 1,25-dihydroxyvitamin $\mathrm{D}_{3}$-receptor (VDR) in cervix carcinoma. Histochem J 30(8): 561-567.

16. Friedrich M, Rafi L, Tilgen W, Schmidt W, Reichrath J (1998) Expression of 1,25-dihydroxyvitamin D3-receptor (VDR) in breast carcinoma. J Histochem Cytochem 46(11): 1335-1337.

17. M Friedrich, C Villena-Heinsen, R Axt-Fliedner, R Meyberg, W Tilgen, et al. (2002) Analysis of 25-Hydroxyvitamin $D_{3}-1 \alpha$-Hydroxylase in Cervical Tissue. Anticancer Research 22(2): 183-186.

18. M Friedrich, R Axt-Fliedner, C Villena-Heinsen, W Tilgen, W Schmidt, et al. (2002) Analysis of Vitamin D Receptor (VDR) and Retinoid X-Receptor $\alpha$ (RXR- $\alpha$ ) in Breast Cancer. Histochem J 34(1-2): 35-40.

19. M Friedrich, L Rafi, T Mitschele, W Tilgen, W Schmidt, et al. (2003) Analysis of the vitamin D-system in cervical carcinomas, breast cancer and ovarian cancer. Recent Results Cancer Res 164: 239-246.

20. Becker S, Cordes T, Diesing D, Diedrich K, Friedrich M (2007) Expression of 25 hydroxyvitamin D3-1alpha-hydroxylase in human endometrial tissue. J Steroid Biochem Mol Biol 103(3-5): 771-775.

21. Scheible C, Thill M, Baum S, Solomayer E, Friedrich M (2014) Implication of CYP24A1 splicing in breast cancer. Anticancer Agents Med Chem 14(1): 109-114.

22. M Friedrich, D Diesing, T Cordes, D Fischer, S Becker et al. (2006) Analysis of 25-Hydroxyvitamin D3-1 $\alpha$-hydroxylase in normal and malignant breast tissue. Anticancer Res 26(4A): 2615-2620.

23. C Villena-Heinsen, R Meyberg, R Axt-Fliedner, K Reitnauer, J Reichrath, et al. (2002) Immunohistochemical analysis of 1,25 Dihydroxyvitamin D Receptors, estrogen and progesterone receptors and Ki-67 in ovarian carcinoma. Anticancer Research 22(4): 2261-2267.

24. D Diesing, T Cordes, D Fischer, K Diedrich, M Friedrich (2006) Vitamin D metabolism in the human breast cancer cell line MCF-7. Anticancer Res 26(4A): 2755-2759.

25. J Reichrath, W Tilgen, K Diedrich, M Friedrich (2006) Vitamin D analogs in cancer prevention and therapy. Anticancer Res 26(4A): 2411-2414.

26. Thill M, Terjung A, Friedrich M (2014) Breast cancer--new aspects of tumor biology: are calcitriol and cyclooxygenase-2 possible targets for breast cancer? Eur J Gynaecol Oncol 35(4): 341-358.

27. Salehin D, Haugk C, Thill M, Cordes T, Hornung D, et al. (2012) Serum 25-hydroxyvitamin D levels in patients with vulvar cancer. Anticancer Res 32(1): 265-270. 
28. Salehin D, Haugk C, Thill M, Cordes T, William M, et al. (2012) Vitamin D receptor expression in patients with vulvar cancer. Anticancer Res 32(1): 283-289.

29. Fischer D, Seifert M, Becker S, Ludders D, Cordes T, et al. (2007) 25-Hydroxyvitamin D3 1alpha-hydroxylase splice variants in breast cel lines MCF-7 and MCF-10. Cancer Genomics Proteomics 4(4): 295-300.

30. Friedrich M, Mink D, Villena-Heinsen C, Reichrath J, Schmidt W (1998) Presentation of an immunoreactivity score for 1,25-dihydroxvitamin D3 receptors (VDR-IRS) in cervix carcinomas. 6th International Conference of Anticancer Research, Kallithea, Halkidi, Griechenland, 21-25 October, 1998. Anticancer Research, 1998, 18 (6C), 4865.

31. Colston KW, Berger U, Coombes RC (1989) Possible role for vitamin D in controlling breast cancer cell proliferation. Lancer 1(8631): 188-191.

32. van Leeuwen JP TM, Birkenhäger JC, Buurmann CJ, Schilte JP, Pols HAP (1990) Functional insolvement of calcium in the homologous upregulation of the 1,25-dihydroxyvitamin D3 receptor in osteoblast-like cella. FEBS Lett 270: 165

33. van Leeuwen JP TM, Pols HAP, Schilte JP, Visser TJ, Birkenhäger JC (1991) Modulation by epidermal growth factor of the basal 1,25- $(\mathrm{OH}) 2 \mathrm{D} 3$ receptor level and the heterologous up-regulation of the 1,25- $(\mathrm{OH}) 2 \mathrm{D} 3$ receptor in clonal osteoblast-like cells. Calcif Tissue Int 49(1): 35-42.

34. Costa EM, Hirst MA, Feldman D (1985) Regulation of 1,25-dihydroxyvitamin D3 receptors by vitamin D analogues in cultured mammalian cells. Endocrinology 117(5): 2203-2210.

35. Krishnan AV, Feldman D (1991) Stimulation of 1,25-dihydroxyvitamin D3 receptor gene expression in cultured cells by serum and growth factors. J Bone Miner Res 6(10):1099-1107.

36. Escaleira MTF, Sonohara S, Brentani MM (1993) Sex steroids induced up-regulation of 1,25-(OH)2vitamin D3 receptors in T47D breast cancer cells. J Steroid Biochem Mol Biol 45: 257.

37. Vink- van Wijngaarden T, Pols HAP, Buurman CJ, van den Bemd GJCM, et al. (1994) Inhibition of breast cancer cell growth by combined treatment with vitamin D3 analogs and tamoxifen". Cancer Res 54: 5711

38. Buras RR, Schumaker LM, Davoodi F, Brenner RV, Shabahand M, et al (1994) Vitamin D receptors in breast cancer cells. Breast Cancer Res Treatment 31(3): 191-202.

39. Fan FS, Yu WC (1995) 1,25-dihydroxyvitamin D3 suppresses cell growth, DNA synthesis, and phosphorylation of retinoblastoma protein in a breast cancer cell line. Cancer Invest 13(3): 280-286.

40. Elstner E, Linker-Israeli M, Said J, Umiel T, de Vos S, et al. (1995) 20-epiVitamin D3 analogues: a novel class of potent inhibitors of proliferation and inducers of differentiation of human breast cancer cells. Cancer Res 55(13): 2822-2830.

41. Narvaez CJ, Vanweelden K, Byme I, Welsh J (1996) Characterization of a vitamin D-resistant MCF-7 cell line. Endocrinology 137: 400.

42. Freake HC, Marcocci C, Iwasaki J, MacIntyre I (1981) 1,25-dihydroxyvitamin D3 specifically binds to a human breast cancer cell line (T47D) and stimulates growth. Biochem Biophys Res Commun 101: 1131.

43. Frampton RJ, Omond SA, Eisman JA (1983) Inhibition of human cancer cell growth by 1,25-dihydroxyvitamin D3 metabolites. Cancer Res 43 : 4443 .

44. Chouvet C, Vicard E, Devonec M, Saez S (1986) 1,25-dihydroxyvitamin D3 inhibitory effect on the growth of two human breast cancer cell lines (MCF-7, BT-20). J Steroid Biochem 24(1): 373-376.

45. Abe J, Nakano T, Nishii Y, Matsumoto T, Ogata E, (1991) et al. A novel vitamin D3 analog, 22-oxa-1,25-dihydroxyvitamin D3 inhibits the growth of human breast cancer in vitro and in vivo without causing hypercalcemia. Endocrinology 129(2): 832-837.
46. Eisman JA, Koga M, Sutherland RL, Barkla DH, Tutton PJM, et al. (1989) 1,25-dihydroxyvitamin D3 and the regulation of human cancer cell replication. Proc Soc Exp Med 191(3): 221-226.

47. Eisman JA, Sutherland RL, McMenemy ML, Fragonas JC, et al. (1989) Effects of 1,25-dihydroxyvitamin D3 on cell cycle kinetics of T474D human breast cancer cells. J Cell Physiol 138: 611.

48. Pols HAP, Birkenhäger JC, Foekens JA, van Leeuwen JPTM (1990) Vitamin D: a modulator of cell proliferation and differentiation. J Steroid Biochem Mol Bio 16: 873.

49. Simboli-Campbell M, Welsh J (1995) 1,25-dihydroxyvitamin D3: coordinate regulator of active cell death and proliferation in MCF7 breast cancer cell. In: Apoptosis in Hormone Dependent Cancers. Springerverlag p. 181.

50. Kerr JFR, Wyllie AG, Currie AR (1972) Apoptosis: a basic biological phenomenon with wide ranging implications in tissue kinetics. $\mathrm{Br} J$ Cancer 26(4): 239-257.

51. Jaines SY, Mackay AG, Colston KW (1995) Vitamin D derivatives in combination with 9-cis-retinoic acid promote active cell death in breast cancer cells. J Mol Endocrinol 14(3): 391-394.

52. Vande Walle B, Homez L, Wattez N, Revilion F, Lefebvre J, et al. (1995) Vitamin-D3 derivatives and breast-tumor cell growth: effect on intracellular calcium and apoptosis. Int J Cancer 61: 806.

53. Vink-van Wijngaarden T, Pols HAP, Buurmann CJ, Birkenhäger JC, van Leeuwen JPTM, et al. (1993) Combined effects of 1,25-dihydroxyvitamin D3 and tamoxifen on the growth of MCF-7 and ZR-75-1 human static carcinoma cell breast cancer cells. Breast Cancer Res Treat 29: 161.

54. Gross M, Bollmann Kost S, Ennis B, Stumpf W, Kumar R, et al. (1986) Effect of 1,25-dihydroxyvitamin D3 on mouse mammary tumor (GR) cells: evidence for receptors, cellular uptake, inhibition of growth and alliteration in morphology at physiologic concentrations of hormone. J Bone Miner Res 1: 457

55. Frappart L, Falette N, Lefebvre MF, Bremond A, Vauzelle JL, et al. (1989) In vitro study of effects of 1,25-dihydroxyvitamin D3 on the morphology of human breast cancer cell line BT20. Differentiation 40(1): 63-69.

56. Colston KW, Chander SK, Mackay AG, Coombes RC (1992) Effects of synthetic vitamin D analogues breast cancer cell proliferation in vivo and in vitro. Biochem Phannacol 44(4): 693-702.

57. Lino Y, Yoshida M, Sugamata N, Maemura M, Ohwada S, et al. (1992) 1a, 25-dihydroxyvitamin D3, hypercalcemia, and growth suppression of 7,12-dimethylbenz(a)anthracene-induced rat mammary tumors. Breast Cancer Res Treat22: 133

58. Saez S, Falette N, Guillot C, Meggouth F, Lefebvre MF, et al. (1993) $1,25(\mathrm{OH}) 2 \mathrm{D} 3$ modulation of mammary tumor cell growth in vitro and in vivo. Breast Cancer Res Treat 27: 69.

59. Noguchi S, Tahara H, Miyauchi K, Koyama H (1989) Influence of 1a, 25-dihydroxyvitamin D3 on the development and steroid hormone receptor contents of DMBA-induced rat mammary tumors. Oncology 46(4): 273-276.

60. Bower M, Colston KW, Stein RC, Hedley A, Gazet JC, et al. (1991) Topical calcipotriol treatment in advanced breast cancer. Lancet 337: 701.

61. O’Brien MER, Talbot D, Maclennan K, Smith IE, et al. (1993) Inefficacy of calcipotriol in skin metastases from breast cancer. Lancet 342: 994.

62. Muss HB (1992) Endocrine therapy for advanced breast cancer: a review. Breast Cancer Res Treat 21: 15.

63. Abe-Hasimoto J, Kikuchi T, Matsumoto T (1993) Antitumor effect of oxacalcitriol, a noncalcemic analogue of calcitriol, in athymic mice implanted with human breast carcinoma and its synergism with tamoxifen. Cancer Res 53(11): 2534. 
64. Anzano MA, Smith JM, Uskokovic MR (1994) 1a, 25-dihydroxy-16-ene23-yne-26,27-hexafluorocholecalciferol (Ro24-5531), a new diltanoid (vitamin D analogue) for prevention of breast cancer in the rat. Cancer Res 54: 1653.

65. Costa A (1993) Breast cancer chemoprevention. Eur J Cancer 29A: 589.

66. Koga M, Sutherland RL (1991) Retinoic acts synergistically with 1,25-dihydroxyvitamin D3 or antiestrogen to inhibit T-47D human breast cancer cell proliferation. J Steroid Biochem Mol Biol 39: 455.

67. Rocker D, Ravid A, Liberman UA, Garach-Jehoshua O, Koren R (1994) 1,25-dihydroxyvitamin potentiates the cytotoxic effect of TNT on human breast cancer cells. Mol Cell Endocrinol 106: 157.

68. Hassan HT, Eliopoulos A, Maurer HR, Spandidos DA (1992) Recombinant human GM-CSF enhances the anti-proliferative activity of vitamin D in MCF-7 human breast cancer clonogenic cells. Eur J Cancer 28: 1588

69. Cho YL, Christensen C, Saunders DE, Lawrence WD, Deppe G, et al (1991) Combined effects of 1,25-dihydroxyvitamin D3 and platinum drugs on the growth of MCF-7 cells. Cancer Res 51: 2848.

70. Mork Hansen CM, Frandsen TL, Brünner N, Binderup L (1994) 1x, 25-dihydroxyvitamin $\mathrm{D}_{3}$ inhibits the invasive potential of human breast cancer cells in vitro. Clin Exp Metast 12: 195.

ISSN: 2574-1241

DOI: 10.26717/BJSTR.2018.08.001645

Michael Friedrich. Biomed J Sci \& Tech Res

(C) (P) This work is licensed under Creative

Submission Link: https://biomedres.us/submit-manuscript.php
71. Hortobagyi GN (1991) Bone metastases in breast cancer patients. Semin Onol 18: 11.

72. Agha FP, Norman A, Hirschl S, Klein R (1976) Paget's disease coexistence with metastatic carcinoma. NY State J Med 76: 734.

73. Fitton A, McTavish D (1991) Pamidronate: a review of its pharmacolohic properties and therapeutic efficacy in resorptive bone disease. Drugs 41: 289.

74. Krempien B, Manegold C (1993) Prophylactic treatment of skeletal metastases, tumor-induced osteolysis, and hypercalcemia in rats with the bisphosphonate CI2MBP. Cancer 72: 91.

75. Krempien B (1984) The Walker carcinoma-sarcoma 256 as an experimental model of bone metastases: influence of local an metabolic factors on incidence and pattern of metastases. Calcif Tissue Int 36: S26.

76. Wright CDP, Garrahan NJ, Stanton M, Gazet JC, Mansell RE, et al. (1994) Effect of long-term tamoxifen therapy on cancellous bone remodelling and structure in women with breast cancer. J Bone Miner Res 9: 153.

77. Vink- van Wijngaarden T, Birkenhäger JC, Kleinekoort WMC, van den Bemd GJCM, et al. (1995) Antiestrogens ihibit in vitro bone resorption stimulated by 1,25-dihydroxyvitamin D3 and the vitamin D3 analogs EB1089 and KH1060. Endocrinology 136: 812.

$\begin{array}{ll}\text { BIOMEDICAL } & \text { Assets of Publishing with us } \\ \text { RESEARCHES } & \text { Global archiving of articles } \\ & \text { - Immediate, unrestricted online access } \\ & \text { - Rigorous Peer Review Process } \\ \end{array}$

